JOALL (JOURNAL OF APPLIVI) LINGUIS'IICS ANI) LI'TERA'TURE)

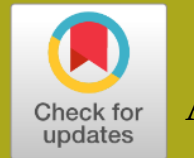

Vol. 6 No. 1, 2021

ISSN (print): 2502-7816; ISSN (online): 2503-524X

Available online at https:/ / ejournal.unib.ac.id/index.php/joall/index doi: http://dx.doi.org/10.33369/joall.v6i1.13314

\title{
CODE-SWITCHING IN INDONESIAN POPULAR SONGS AND ITS POTENTIAL IMPLICATIONS FOR ENGLISH LANGUAGE TEACHING
}

\author{
Rahmawaty Kadir \\ University of Alberta, Canada \\ Corresponding email: rahmawat@ualberta.ca
}

\begin{abstract}
Code-switching is a common phenomenon in a bilingual and multilingual society. People utilize codes in different forms of interactions for various reasons and functions. This descriptive qualitative study investigates the types and functions of code-switching between English and Bahasa Indonesia that occur in the song lyrics. Fifteen Indonesian songs produced from 2009 to 2019 were examined. The content analysis reveals that four types of code-switching occur in the lyrics of Indonesian popular songs: code-switching between sentences (intersentential), code-switching within sentences (intrasentential), code-switching involving changes of pronunciation, and emblematic code-switching. It further reveals that the functions of code-switching in the lyrics vary from discussing particular topics, lexical needs and availability, being emphatic, expressing group identity, simplifying words and expressions, and conveying a strong emotion/gaining attention.
\end{abstract}

Keywords: Code-switching, popular songs, intrasentential, intersentential, emblematic

\section{INTRODUCTION}

Multilingual people typically use a particular code in verbal or nonverbal communication. Bilingual or multilingual people may also decide to switch from one code to another or to mix codes, even within very brief utterances or a short-written line. This process is known as code-switching (Wardhaugh \& Fuller, 2015) or language alternation (Auer, 1998). The terms code and language are often used interchangeably (Muysken, 2000; Wardhaugh \& Fuller, 2015). Wardhaugh and Fuller (2015) categorize code as a language or a variety of a language including dialect, style, and register. The term code is seen as a neutral concept of a linguistic variety as it covers a language or a 
dialect. For the purpose of this study, both notions are also utilized identically because they are not the focus to be discussed.

Researchers have provided different definitions of code-switching (hereafter CS). A general description of CS suggested by Gumperz (1982) is "the juxtaposition within the same speech exchange of passages of speech belonging to two different grammatical systems or subsystems" (p. 59). Similarly, Myers-Scotton (2006) defines CS as including elements from two (or more) language varieties in the same clause. Still, only one of these varieties is the source of the morpho-syntactic frame for the clause (p. 241). Another important definition is given by Milroy and Gordon (2003) who describes CS as, "a range of language (or dialect) alternation and mixing phenomena whether within the same conversation, the same turn, or the same sentence utterance" (p. 209). It is important to note that all these researchers share a common view of the phenomenon of CS and use the term CS as an umbrella term to include all types of language contact phenomena within the sentence boundary or beyond that. This study will use the term code-switching as an umbrella term to cover the phenomenon of alternating between two languages within the lyrics or the same written line.

Although the concept has been widely studied, the majority of codeswitching research has often been restricted to conversations in bilingual communities. As the informal conversation is considered a spontaneous act, people code-switch back and forth naturally in many different settings. Gumperz (1982) is one of the earliest scholars who studied code-switching in conversation. He focuses on metaphorical switching, where the switches take place because of the social relationship between the speakers (Gumperz, 1982). Gumperz (1982) cites examples of metaphorical code-switching from three sets of languages (Hindi and English, Slovenian and German, and Spanish and English) to show how speakers employ particular languages to convey information that goes beyond their actual words, especially to define social situations.

Code-switching in conversation is very different from the one found in music (Bentahila and Davies, 2002; Sarkars \& Winer, 2005). According to Bentahila and Davies (2002) in song lyrics, CS does not happen spontaneously or intimately. Furthermore, it is not addressed to one speaker, or to a specific group known personally to the speaker as it happens in conversation. Their study of CS between French and Arabic in Algeria indicates two different roles of CS: "globalization and localization" (Bentahila \& Davies 2002, p. 206). Their analysis reveals the singers' intentions to connect with the international society in the local context. In another study, Davies and Bentahila (2008) show how CS relates to the structure of the "rai" lyrics. They perceive that CS is aimed to deliver rhetorical and aesthetic effects in the lyrics. In addition to being a useful resource for bilinguals in everyday interaction with other 
bilinguals, CS may also serve a poetic function, not spontaneous, but carefully constructed. Therefore, CS that naturally occurs in conversation is different from CS in lyrics. CS in lyrics is a purposeful language alternation used by singers and song composers who have planned, written, and reflected upon lyrics even before the release of their songs.

In music, singers are aware of the chance that their words may be received by people outside their context of language use. According to Davies and Bentahila (2006), in song lyrics, singers are often motivated by the development of media and the internet that provides exceptional prospects for people all over the world to be exposed to music from different cultures. Therefore, singers who look for success in the popular music industry use code-switching as a "stylistic innovation" in their song lyrics (Bentahila and Davies, 2006, p. 368). Similarly, Babalola and Taiwo (2009) explain that CS in songs permits the singers to share their culture artistically.

CS can be viewed from a linguistic perspective and a sociolinguistic perspective. According to Hoffmann (2014), linguistically, there are three types of code-switching: intersentential code-switching, intrasentential codeswitching, and emblematic switching. Intersentential CS involves switches from one language to another between sentences. For example, when an Indonesian-English bilingual says, "this food is too spicy, perlu tambah garam sedikit" (it needs to add a bit of salt). Intrasentential switches occur within the same sentence, and can involve different units, from a single morpheme to a clause as when an Indonesian- English bilingual says "dia benar-benar (he is really) lazy, taunya (he knows only) clubbing tiap malam (every night)". Furthermore, emblematic switching is used for continuity with the previous speaker and includes tags or exclamations, switches that involve pronunciation features, or a word within a sentence, which can be a noun, adjective, verb, or adverb. An example of emblematic switching that involves the insertion of a tag phrase is "watch out! disana agak basah (it's slightly wet over there)".

Blom and Gumperz (1972) analyze CS from a sociolinguistic view, which consists of situational CS and metaphorical code-switching. Situational CS occurs when a language is used based on the situation that the speakers find themselves in. The speakers will speak the same language in one particular situation and another language in a different situation. In contrast, metaphorical CS requires speakers to change topics when they change the language they use (Wardhaugh \& Fuller, 2015).

An example of situational CS, according to Blom and Gumperz (1972), is when a teacher utters formal speech in Bokmål, the standard language of Norway, and then continues the discussion in Ranamal, a local Norwegian dialect considered less formal. In addition, for metaphorical switching, they are given an example of CS between a government officer and a local citizen 
when they have a business transaction. Even though most of the language used is Bokmål, they also used Ranamal to express particular meanings in their conversation (Blom \& Gumperz, 1972).

Code-switching happens for many possible reasons. Intention to maintain power and solidarity is seen as one of the most common reasons for people to CS. Wardhaugh and Fuller (2015) note, "CS provides a somehow similar example of another code deliberately fashioned to achieve a distinct identity while at the same time creating a link with another group of similar status in the community" (p.103). In music, as mentioned by Davies and Bentahila (2006), the targets are not only in immediate contexts known by the speakers as it may open to the people worldwide. Therefore, the singers may choose to switch to another language.

Another function of CS is discussing a particular topic (Hoffmann, 2014). Discussion about specific issues may cause CS either because of a lack of facilities in a relevant code or because of various connotations that are linked to experiences in a particular language. Similarly, Myers Scotton (1993) argues a lack of knowledge of one language or lack of available choices in that language on one specific subject prompt CS. Moreover, CS occurs when the speaker intends to quote somebody else. Hoffmann (2014) mentions that people enjoy quoting famous expressions or sayings of prominent figures. Through maintaining the original words used by well-known speakers, people aimed to transfer the meaning to others as clearly as possible in their conversation. To speak emphatically about something comes as the next function for CS. According to Hoffmann (2014), people tend to transfer from one language to another when they want to be emphatic or to show sympathy about something.

Moreover, when expressing sudden emotions or feelings, people tend to switch languages. Gumperz (1982) refers to this purpose as an "interjection or sentence filler," which may happen intentionally or unintentionally (p. 77). Repetition used for clarification may also motivate people to code-switching. The use of repetition in CS is to check understanding (Gumperz, 1982) and to ensure that the message was delivered following the quotation (Mattsson \& Burenhult, 1999). CS may also intend to fulfill the speaker's intention and desire to be understood.

Last but not least, showing prestige is also linked with the CS phenomenon in the bi/multilingual community (McArthur, 2003). In fact, when a language is recognized as a dominant language by a particular group and has a special status in the country, the language ultimately will have prestige and value by its own community and even by people outside the community. Often, a language associated with religion, education, and the nation are prestigious. For example, in the Javanese language, to be recognized as belonging to a royal and educated family, Javanese people 
code-switch from kromo ngoko (the lower-level language) to kromo inggil (the higher-level language). Therefore, people may alternate code from a less prestigious language to a higher language status.

Indonesia is an archipelago country with more than 18,000 islands and about 700 Indigenous languages. Therefore, many Indonesians are mostly bilingual or even multilingual. Indonesians are fluent speakers of their native language and the Indonesian language or Bahasa Indonesia (hereafter BI), which also serves as the country's official language. While Arabic is used in religion-related activities, many Indonesians can communicate in English, particularly those who live in urban areas. As a foreign language, English has been taught at high schools and universities across the country since the late 1960s and has gradually spread to elementary and middle schools in the intervening decades. Slowly but surely, English has entered not only the education field but social and economic areas too, for instance, in advertisements, literature, movies, newspapers, and song lyrics.

Words in English first appeared as song titles in many Indonesian popular songs and albums in the 1970s. However, one of the earliest famous songs that included code-switching between BI and English was from the band Slank recorded in 2000, "I miss you, but I hate you". Later, more singers in Indonesia have begun to use English and Indonesian words in their lyrics.

Bahasa Indonesia (BI) has continuously adopted a variety of characteristics from English. Consequently, English has influenced BI at all levels, whether in phonology, morphology, semantics, and syntax, with one of the most remarkable influences being the mixing of English in BI oral and written forms. As code-switching frequently occurs in many genres of verbal communication, most studies about CS are mainly focused on daily conversation (Gumperz 1982; Myers-Scotton, 1993; Poplack, 1980). However, Davies and Bentahila (2006; 2008) acknowledge that CS in novels, poems, and song lyrics can also be observed. This study observes the code-switching behaviours that occurred in song lyrics following Hoffmann's (2014) framework. In short, this study attempts to explore the following questions: (1) What types of CS do Indonesian singers/artists use in their lyrics? (2) What seems to be the factors that influence the use of CS in song lyrics?

This research offers a beneficial comparison for other similar studies in exploring the use of CS in English and BI or other varieties of languages in Indonesia in different contexts. Finally, this study is expected to inform English foreign language teachers about the implications of code-switching in EFL classes.

\section{METHODS Data Collection}


Data in this study were collected by using the purposive sampling technique, which is defined by Creswell (2007) as a sampling technique that allows the researcher to select participants and research sites that are associated with the phenomenon and research problems being studied. CS in Indonesia's pop songs is a common phenomenon among singers and song composers, consequently, it leaves the researcher with too many options to choose from. Therefore, the data in this study were selected based on the following criteria:

a) Selecting 15 pop songs from Prambors FM Radio's top 40 song charts from the period of 2009 to 2019.

b) They were performed by young singers aged 20-40 who represent the younger generations of Indonesian society.

c) The song lyrics use more than one language: Bahasa Indonesia and English.

These 15 songs have been listed in the top 40 charts of Prambors FM Radio, a commercial radio network based in Jakarta, Indonesia. This pop music radio station targets teenagers and young adults as its main audience. Most of these songs have obtained over a million views on YouTube. Because of their popularity, they are quite familiar among children, youth, and even middle-aged people. The fifteen Indonesian songs are presented in Table 1.

Table 1. List of Indonesian pop songs involved in this study with year, artists, and awards

\begin{tabular}{|c|c|c|c|c|}
\hline No & Songs & Year & Artist & Awards / Recognitions \\
\hline 1. & "Ziggi Zagga" & 2019 & Gen Halilintar & $\begin{array}{l}\text { Top radio song chart, trending } \\
\text { number \#1 on YouTube on } \\
\text { February } 2019\end{array}$ \\
\hline 2. & "Ragu" & 2019 & Rizki Febrian & $\begin{array}{l}\text { Top radio song chart, seven } \\
\text { million views on YouTube }\end{array}$ \\
\hline 3. & "Flashback" & 2018 & $\begin{array}{l}\text { Anji featuring } \\
\text { YoungLex }\end{array}$ & $\begin{array}{l}\text { Top radio song chart, trending } \\
\text { number } \# 25 \text { on YouTube on } \\
\text { December } 2018\end{array}$ \\
\hline 4. & $\begin{array}{l}\text { "Bright as the } \\
\text { Sun" }\end{array}$ & 2018 & $\begin{array}{l}\text { All Indonesians } \\
\text { Singers }\end{array}$ & $\begin{array}{l}\text { Top radio song chart, official } \\
\text { song for ASIAN games } 2018\end{array}$ \\
\hline 5. & $\begin{array}{l}\text { "Let It Be My } \\
\text { Way" }\end{array}$ & 2016 & Andien & $\begin{array}{l}\text { Top radio song chart, movie } \\
\text { soundtrack }\end{array}$ \\
\hline 6. & $\begin{array}{l}\text { "Rock and } \\
\text { Love" }\end{array}$ & 2016 & Kotak & $\begin{array}{l}\text { Top radio song chart, movie } \\
\text { soundtrack }\end{array}$ \\
\hline 7. & "Move On" & 2014 & Project Pop & Top radio song chart \\
\hline 8. & “Di Reject" & 2013 & Jenita Janet & $\begin{array}{l}\text { Top radio song chart, } \\
\text { Nomination for Dangdut song } \\
\text { in Inbox awards } 2013\end{array}$ \\
\hline 9. & "Paralyzed" & 2012 & Agnes Monica & $\begin{array}{l}\text { Top radio song chart, the most } \\
\text { popular regional song in }\end{array}$ \\
\hline
\end{tabular}


Code-switching in Indonesian Popular Songs and its Potential ....

\begin{tabular}{|c|c|c|c|c|}
\hline No & Songs & Year & Artist & Awards / Recognitions \\
\hline & & & & $\begin{array}{l}\text { JPopAsia Music Awards, } \\
\text { nomination for Intuned Music } \\
\text { Awards }\end{array}$ \\
\hline 10. & “Unity" & 2012 & $\begin{array}{l}\text { Bondan Prakoso \& } \\
\text { Fade to Black }\end{array}$ & Top radio song chart \\
\hline 11. & "I Heart You" & 2011 & Smash & $\begin{array}{l}\text { Top radio song chart, the most } \\
\text { inbox song in Inbox music } \\
\text { awards, Ancora Music's Milion } \\
\text { Awards. }\end{array}$ \\
\hline 12. & "Fivers" & 2011 & Five Minutes & Top radio song chart \\
\hline 13. & “Let Me Go" & 2010 & Cinta Laura & Top radio song chart \\
\hline 14. & $\begin{array}{l}\text { "Cinta Atau } \\
\text { Uang" }\end{array}$ & 2010 & Cinta Laura & $\begin{array}{l}\text { Top radio song chart, } \\
\text { Indonesian Music Awards } \\
2011 \\
\text { Movie soundtrack } \\
\text { FTV Awards } 2011\end{array}$ \\
\hline 15. & $\begin{array}{l}\text { "Kapan Lagi } \\
\text { Kau Bilang I } \\
\text { Love You" }\end{array}$ & 2009 & Dewi Sandra & Top radio song chart \\
\hline
\end{tabular}

\section{Data Analysis}

The fifteen lyrics of Indonesian songs examined in this paper were obtained from the internet and the official website of the singers. Each of them was cross-checked at least twice against the recorded versions of the song's official video. Furthermore, the lyrics from the internet that are not transcribed well were revised accordingly. When the transcription process was completed, every English word, phrase, and clause was highlighted to indicate the switches. The lyrics were then given a number following the date of the song's release. All the lyrics included in the analysis were provided gloss translation followed by the English translation. Finally, all the lyrics that contain CS were then categorized according to the types and functions discussed in the previous section.

\section{FINDINGS}

\section{Types of Code-Switching}

Based on the analysis of the data, four kinds of CS are found in Indonesian popular song lyrics; intrasentential code-switching, intersentential codeswitching, and emblematic CS, which involves exclamations, and a change of pronunciations.

\section{Intrasentential Code-Switching}


The following examples are of intrasentential CS that appear in Indonesian popular songs. In each excerpt, the first line represents the original lyrics of the song (italics for English words and regular font for Bahasa Indonesia), the second line is the gloss translation to English, and the third line is the English functional translation.

(1) Traveling dikit, kita langsung nge-spam

Travelling a bit, we straight make-spam

"Just a bit of travelling, we straight make spams"

(2) Spot bagus lomba siapa upload duluan

Spot good compete who upload first

"Find a good spot; we compete who will upload first"

(Gen Halilintar, "Ziggi Zagga”)

In excerpts (1) and (2), the English words traveling, spam, spot, and upload serve as nouns and verbs used in the lyrics. The position of switching appears at the beginning, middle, and end of the sentence. Note that the codeswitched forms in the lyrics above do not violate the grammatical rules of either BI or English, and those entire structures are well-formed.

(3) Cukup jalani dan rasakan ohh my lady Simply live and feel oh mylady "Simply live and feel ohh my lady"

(Rizky Febrian, “Ragu”)

In excerpt (3), the English phrase, my lady occurs after a phrase in BI. This also means the process of switching code to English happened at the end of the sentence. Therefore, this type of CS fulfills the category of intrasentential CS.

(4) Lagu yang sering kita dengar buatku flashback Song that often we listen make-POSS flashback

"The song that we often hear gives me a flashback"

(5) Film yang kita tonton buatku flashback

Movie that we watch make-POSS flashback

"The movie that we watch makes me flashback"

(6) Chatting sampai tengah malam

Chatting until midnight

"Chatting until midnight"

(Anji \& Young Lex, "Flashback") 
In Anji and Young Lex's song, there are some applications of English words that function as nouns, such as flashback and chatting. There is no violation of the grammatical structure of the sentences in BI as well as English. Furthermore, the position of switching in excerpts (4) and (5) are at the end of the line, while in (6) it is at the beginning of the line.

(7) Kamu rock'n'roll, kamu rock'n'love

You rock'n'roll, you rock'n'love

"You are rock' $n^{\prime}$ roll, you are rock' $n^{\prime} l o v e "$

(8) Jiwa rock and love yang akan bertahan

Soul rock and love, which will last

"The soul of rock and love will last"

(Kotak, “Rock'n'Roll”)

(9) Kau putuskan aku lihat statusku jadi Goodbye pacar sialan, uwooooo

You broke up me see status-POSS so goodbye boyfriend damn, uwooo

"You broke up with me because of my status so goodbye damn boyfriend, uwooo"

(10) Caranya gak repot-repot yo party bareng Project Pop

Way notbother yeah party with project pop

"The way is not bothering yeah party with project pop"

(11) Yo yo check it out hati galau galau galau galau harus disetop

Yo-yo check it out heart confused confused confused confused must

(passive)-stop

"Yo-yo check it out a confused heart must be stopped"

(Project Pop, "Move on")

Kotak and Project Pop are two musical groups that often utilize English words or sentences in their songs. The phrases rock and roll, and rock and love are repeated throughout Kotak's music because they also serve as the title of the song. The position of switching from BI to English relatively fits within the sentence. Moreover, in Project Pop's lyrics, the process of switching nouns and phrasal verbs occurs in the beginning and at the middle of the sentence without violating the sentence structures of both languages.

(12) Kamu calling-calling, aku lagi pusing

You call, I (be) dizzy

"You keep calling, I am dizzy" 
(13) Di-reject, di-reject, di-reject aja pacar yang tak setia usah ditanggapi (passive)-reject just boyfriend who not faithful do not respond "rejected, rejected, just rejected, an unfaithful boyfriend, does not need to respond"

$$
\text { (Jenita Janet, “Di reject") }
$$

The position of switching from BI to English occurs in the middle (12) and at the beginning of the phrases (13). The words calling and reject serve as verbs in these two lyrics. Note that the reduplication of words or phrases such as calling-calling does not exist in English. However, to create a correct structure and intensification meaning in BI, the lyric (13) needs reduplication of the verb calling. Moreover, in line (14), there is a BI prefix-di that is followed by an English verb reject. This BI prefix is added to create a passive verb meaning.

$$
\begin{aligned}
& \text { Prepare untuk Bersatu } \\
& \text { Prepare for unity } \\
& \text { "Prepare for unity" }
\end{aligned}
$$

(15) Semua bergerak.. UNITY

$$
\text { All move... UNITY }
$$

(Bondan feat. Fade to Black, "Unity")

Based on excerpts (14) and (15) above, there are two English words; prepare and unity used in the lyrics. The switch to English fulfills the structural and grammatical needs of the lyrics.

(16) Lama-lama ku pikir jadi ngga worth it gini

Long I think so no worth it now

"After a long time, I think it is not worth it now"

(17) Lebih baik aku hang out bersama temanku Better I hang out with friend-POSS

"It is better if I hang out with my friend"

(18) Kamu cheating-in aku yang setia denganmu You cheat me who faithful with POSS

"You are cheating on me who is faithful to you"

(Cinta Laura, "Let Me Go")

In the song by Cinta Laura entitled "Let Me Go", there are intrasentential code-switches. The singer uses English words and phrases 
such as worth it, hang out and cheat. These three words have BI equivalent verbs (berharga "worth," berkumpul "hang out," and selingkuh "cheat"). Note, in (18), there is a suffix -in which was derived from one of the local Indonesian languages, namely Betawi dialect.

\section{Intersentential Code-Switching}

The following examples are intersentential CS that were found in Indonesian songs.

(19) We're zig zag family sebelas anak plus orang tua We $(\mathrm{Be})$ zig zag family eleven children plus parents "We are zig-zag family eleven children plus the parents"

$$
\text { (Gen Halilintar, “Ziggi Zagga”) }
$$

In excerpt (19) there are two types of CS. "We're zig zag family" is categorized as intersentential code-switching because the main lyrics of this song are in Bahasa Indonesia. However, the sequence in this line begins with an English clause and completes the rest of the line in BI. In the second clause, there is a BI clause "sebelas anak plus orang tua". Notice that the English word plus is inserted. Therefore, the second clause can also be categorized as intrasentential code-switching.

(20) Keluarga halilintar you can call us whatever

Family Halilintar you can call us whatever

"The Halilintar family, you can call us whatever"

(Gen Halilintar, “Ziggi Zagga”)

In excerpt (20), there is a switch from a clause in BI to the English clause that happens at the end of the line. Here, keluarga halilintar is considered as a clause, although it does not have a verb form. This occurs because not all clauses in BI require a verb form. These are known as verbless clauses (Moeljadi et al., 2016). Moeljadi et al. (2016) state that BI has multiple copula verbs, distributed over different semantic relations, and the same time, has 'verbless clauses. Basic copula clauses in Indonesian can roughly be divided into three types, depending on the part-of-speech of the predicate: noun phrase (NP), adjective phrase (AP), or prepositional phrase (PP). They may appear in verbless clauses, for example:

John Pandai (adjective phrase), John (is) smart.

(21) Jangan pernah putus asa jadi yang terbaik show the world Do not giveup be the best show the world "Do not give up to being the best, show the world"

(All Indonesian Singers, "Bright as the sun") 
Similarly, in excerpt (21), an English clause appears after a clause in BI. This indicates a switch code from BI into English that can be categorized as an intresentential code-switching.

(22) Let it be my way aku yang rasakan

Let it be my way I who feel

"Let it be my way I am the one who feels it"

(Andien, "Let it be my way")

(23) We're gonna move on hati galau hanya bikin orang blo' on We (be) going to move on heart confused only makes people whacky "We are going to move on; a confused heart only makes people whacky"

(Project Pop, “Move On”)

For (22) and (23), both of the lyrics begin with an English clause followed by a clause in BI "hati galau hanya bikin orang bloon".

(24) Bersamamu tabu bagiku now baby boy listens to me boy show me with (POSS) taboo for (POSS) now baby boy listens to me boy show me

"Being with you is taboo for me, now baby boy listens to me, boy show $m e^{\prime \prime}$

$$
\text { (Agnes Monica, "Paralyzed") }
$$

The lyrics in excerpt (24), were taken from Agnes Monica's song. The CS in this line occurs as intersential code-switching, where the position of switching from BI to English is at the end of the line.

(25) Spread a love, let it high fly to the sky kepalkan telapak tanganmu yang keras

Spread a love let it high fly to the sky clench your fist strongly "Spread a love, let it high fly to the sky clench your fist strongly"

(26) Stand up and get up so come on put your hands up Bhineka tunggal ika satu dalam rasa Stand up and get up so come on put your hands up Bhineka tunggal ika one feel "Stand up and get up so come on put your hands up Bhineka tunggal ika one feels"

(Bondan Feat Fade2Black, "Unity")

For excerpts (25) and (26) above, there are intersentential switches that occur at the beginning of each line. Note, Bhineka Tunggal Ika means unity in 
diversity. It is the official national motto of the Republic of Indonesia, derived from the Sanskrit and Old Javanese.

(27) Hatiku rasakan cinta, dia buatku salah tingkah I know you so well Heart (POSS) feel love, she makes me nervous I know you so well "My heart feels love, she made me nervous I know you so well"

(Smash, "I Heart You”)

The lyrics in (27), contain intersentential CS where the English clause comes after BI. Both English and BI have an independent clause. The switch from BI to English occurs at the end of the line.

(28) Tunggu pembalasanku you are gonna pay for it Wait revenge-POSS you are gonna pay for it "Wait for my revenge; you are gonna pay for it"

(Cinta Laura, "Let me go")

(29) Ku tak butuh uangmu, uangmu I just need your love I do not need money (POSS) money (POSS) I just need your love "I do not need your money; I just need your love"

(Cinta Laura, "Cinta atau uang")

In (28) and (29), the singer uses two complete clauses of English and BI. The switches from BI to English in each line appear at the end of the line.

(30) Kapan lagi kau bilang I love you

When again you say I love you

"When you say I love you again"

(Dewi Sandra, "Kapan Bilang I Love You”)

The lyrics in excerpt (30) are taken from Dewi Sandra's song. There is an intersentential switch from BI to English, which occurs within the line. The lyrics in this line start with a clause in BI and complete the rest of the line with an English clause. Therefore, the switch to English happens at the end of the line.

\section{Emblematic Code-Switching}

Emblematic code-switching in Indonesian popular songs can be found in the following examples.

(31) Satu jiwa $(u g h)$, satu darah (yeah), Satu rasa (c'mon), satu cinta One soul (ugh), one blood (yeah), one feeling (c'mon), one love "One soul (ugh), one blood (yeah), one feeling (c'mon) one love"

(Bondan feat. Fade to Black, "Unity”)

(32) Oh my God terima kasih atas ayah ibu kami 
Oh my God thank you for father mother our

"Oh my God, thank you for our father and mother"

(Gen Halilintar, "Ziggi Zagga”)

(33) Hey you know jadi woles mata banyak nangis bikin males Hey you know so enjoy eye (PLU) a lot of cry makes lazy

"Hey you know, so enjoy, because a lot of crying makes lazy"

(34) Muka jelek ouw what a mess lets party baby pasti beres Face ugly ouw what a mess lets party baby definitely okay "Ugly face ouw what a mess lets party baby it's definitely okay"

(Project Pop, “Move On”)

Excerpt (31) is taken from a hip-hop song performed by Bondan and his group, Fade to Black. As we can see, in the excerpt (31), there are emblematic switching for the exclamations (ugh, yeah, and $c^{\prime}$ mon). In excerpts (32), (33), and (34), the phrase hey you know, what a mess, and let's party appear within the sentence. These phrases are also categorized as emblematic phrases.

\section{Code-Switching Involving a Change of Pronunciation}

Code-switching that involves a change of pronunciation can be found in songs from Bondan feat. Fade to Black, Gen Halilintar, and Project Pop.

(35) Yeah ini adalah cara yang sama untuk me-respek perbedaan

Yeah this is way which same to respect difference

"Yeah, this is the same way to respect the difference"

(36) Kalian para poser dari tokoh nonsen

You the poser of character nonsense

"You are the posers of a nonsense character"

(Bondan feat. Fade to Black, "Unity")

(37) Mengundang atensi segala mata

Invite attention all eyes

"Invite the attention of all eyes"

(Gen Halilintar, “Ziggi Zagga”)

(38) Ayo kita kemon

Let us come on

"Let us come on"

(Project Pop, “Move On”) 
(39) Kamu miscal aku, aku lagi dongkol

You miscalled me, I am cranky

"I am cranky when you call me"

(Jenita Janet, "Di reject")

(40) Fivers tetaplah kau di sini, kibarkan bendera kita

Fivers stay you here, wave flag our

"Fivers stay here, wave our flag"

(Five Minutes, "Fivers")

In excerpts (36), (37), (38), (39), and (40) above, some English words are written in incorrect English spellings because they have been modified. These words are merespek (should be respected, me- is a prefix in BI that forms a verb), atensi (for attention), kemon (for come on), miscal (for miscalled), fivers (for five, the suffix -er is added to make nouns mean person/group and the suffix -s to make the noun plural).

\section{Functions of Code-Switching}

Based on the analysis, it was found that code-switching in Indonesian popular songs appeared when the singers mentioned particular topics such as music, party, and love that can be seen in excerpts (10), (29), (30), and (34). Another function of code-switching can also be seen in excerpts (1), (3), (4), (9), (12), (15), (16) (17), (18), (36), and (37). In these excerpts, it seems that the singers switch to English words to simplify the words. In Except (1) for example the word traveling is the English translation of jalan-jalan, (3) my lady is for kekasih wanitaku, (4) flashback is for terkenang kembali, (9) goodbye is for selamat tinggal, (12) calling is for menelpon, (15) unity is for persatuan, (16) worth it is for berharga, (17) hang out is for bergaul, (18) cheating is for selingkuh, (36) nonsen (supposed to be nonsense) is for tidak masuk akal, and (37) atensi is for perhatian. It is clear that English words have shortened syllabus compared to Indonesian words; therefore, the singers switch to English.

To fulfill lexical needs and availability also led to code-switching. In nge-spam, spot, upload, di-reject, and miscall are words that are associated with technology such as computers and mobile phones. Rock-and-roll, check it out, and poser, are utilized because the singers prefer to use English words translating such words to Indonesian might cause them to be less semantically correct, and sometimes they cannot be used. Additionally, another function of CS that was found in the songs is intentions to show empathy and sympathy. Let it be my way, we're gonna move on, and I know you so well, might indicate that the singers desire to be sympathetic and share the same feeling with others. In excerpt (23) "we are going to move on; hati galau hanya bikin 
orang bloon" the singers aim to show their sympathy toward someone who just broke up and who fails to achieve their ambition. In (22), "let it be my way aku yang rasakan" indicates the feeling of pity towards themselves. In (27) "Hatiku rasakan cinta, dia buatku salah tingkah I know you so well", there is an intention to display empathy toward the spouse or partner. In expert (38) ayo kita (let us) kemon (come on), the songwriter switched from BI to English to repeat the phrasal verb "come on," although the English spelling is incorrect. This switch might be done because the singer wants to emphasize the fact they need to let (someone) go or they need to move on.

It is also found when the singers attempted to convey strong emotions or to gain the listeners' attention, they switched to English. This function of CS can be found in excerpts (31), (32), (33), and (35). Finally, in excerpts (19), (20), (21), and (40), there were also observed functions of code-switching as a means to express identity as an individual or as a group.

\section{DISCUSSION}

Several types of code-switching appeared in Indonesian popular songs: intrasentential code-switching, intersentential code-switching, and emblematic CS, which involves exclamations, and a change of pronunciations. Intrasentential CS is when the switch occurs within a clause, phrase, or word level (Hoffmann, 2014) and it is usually performed without stop, interruption, or hesitation (Poplack,1980). In the song lyrics, the switch may exist in the lyrics' lines or verses. The analysis revealed that there were 18 excerpts of Intrasentential CS that were found in Indonesian popular songs. The position of switching appeared at the beginning, middle, or the last part of the line. Furthermore, each switch did not breach the grammatical structure of each language. English and Indonesia are syntactically mostly similar in simple phrases and sentences (British Council, 2021). Therefore, the switch can take place everywhere in the beginning, middle, or end of a line whether its noun, phrase or a clause. This finding is in line with Gumperz (1982) who stated that when the two languages are syntactically comparable, switches can happen almost anywhere.

Almost all Indonesians are bilingual or even multilingual, switching from Indonesian to other local languages or dialects is a common practice. English has also become the most popular foreign language. In the songs, it appeared that the singers switched from Indonesia to English smoothly and fluidly without violating each language grammar. Code-switching in bilinguals occurs effortlessly and abides by semantic and syntactical rules of each language (Muysken, 2000). Intrasentential CS required the most advanced fluency of all types of CS because it requires bilingual speakers to have satisfactory comprehension of the syntax rules of both languages (Poplack,1980). In music, the lyrics are prepared long before the release of the 
song, therefore, the singers have already been informed and learned which part needs to be in Indonesia or English. Yet, knowledge of English and Indonesian is essential to be able to create a lyric that contains CS.

The second type of CS that appeared in this study is Intersentential CS. This type of CS occurs from one language variety to another language at the sentence, or discourse boundaries (Wardhaugh, \& Fuller, 2015). There were 12 intersentential CS discovered in this study with all songs have base lyrics in Indonesian. Many of the lyrics switched to English in refrain or last verses. Some songs also appeared to begin with English clause then switched to Indonesia in a single line or verse. It is important to note that each language has a complete clause... Emblematic CS or tag switching comes next type of CS observed in this study. It is defined as an insertion of a formulaic fixed expression of multiword combinations. An example of this type of CS can be seen in the excerpt (31), (32), (33) and (34).

The study also discovered that there was a type of CS that involves a change of pronunciation. This type of CS occurred at the phonological level, as when Indonesian speakers modify an English word into the Indonesian phonological structure. Five excerpts were found within the songs: merespek, atensi, kemon, miscal, fivers. There is an Indonesian prefix -me added to the English word respect. While atensi is supposed to be pronounced as attention. The same things occur for kemon (come on), and fivers (five). In excerpt (40) fivers is used instead of five by adding English suffix -er to create a noun, meaning a person belonging to a group. Overall, this study discovered that intrasentensial CS is the most common type of CS in Indonesian popular songs. This also might indicate that words and phrases in English have become popular in Indonesia.

Moreover, several functions of CS were discovered in Indonesian popular songs. These functions are the following:

\section{Intention to Talk about Particular Topics}

Code-switching in the music industry is performed because the singers intended to introduce their music to their community as well as to be accepted by the global community (Bentahila and Davies, 2002). As revealed in this study, the singers seem to feel more comfortable expressing their feelings and ideas in a language that is not their everyday language. When the singers mentioned particular topics such as music, party, and love, they tend to use English words instead of BI.

This switch possibly happens because the word love is also not directly spoken among Indonesians in their conversation. Refraining from displaying positive or negative feelings in public is essential (Korneliussen, 2012; Wieringa, 2010). Consequently, the use of English phrases might be a better option in expressing the message. Another possible reason is in $\mathrm{BI}$, the word 
love has two different meanings: cinta and sayang, which may create a mixup. Cinta is seen as a more rigid formal form of expression. It also has a more powerful and deeper meaning compared to sayang. The word cinta is generally used to describe the feeling of love for family members and one's spouse. On the other hand, the word sayang is less intense, and it is used to describe love for a friend and for a lover. This definition is different than in English, where the word love can be used to convey an intense feeling for all. Therefore, to avoid confusion, the singers prefer to use the word love, which is a common term. Moreover, the singers tend to switch to English to talk about controversial topics such as music and parties. Since modern music and nightlife parties are unfavourable in some Indonesian cultures and religions, this could be the reason for CS to English when talking about particular topics that might be unpopular. Additionally, there is a possible fear that the music video, showing the singer in a nightclub, might promote nightlife styles among Indonesian teenagers. It can be said that with intrasentential code, the singers attempt to camouflage specific topics that are unpopular to be spoken out loud. Therefore, to reach the global population and preserve harmony the singers used intersentential CS to English to serve this purpose.

\section{Intention to Simplify Words and Expression}

The study discovered that the intention to simplify words and expressions in BI or English triggered code-switching. Gumperz (1982) suggests that bilinguals or multilinguals tend to use the shortest and the most straightforward words to ease their communication. However, since Gumperz's (1982) study focused on conversational code-switching, it is essential to note that in the song lyrics, a line of lyrics is constructed by a fixed number of syllables, to follow the beat of the rhythm. Therefore, reducing the syllables of words may help to suit the musical beat. It is quite evident that most of the English words found in this study are shorter than BI. The word travelling in the excerpt (1), for example, is shorter than the Indonesian word jalan-jalan. Words with fewer syllables might be much easier for the singer to fit the rhythm. Overall, the intrasentential CS type is found within the lyrics with the intention to simplify the words or expressions.

\section{Lexical Needs and Availability}

People code-switch to another language more often because finding the exact translation in their language is more complicated than using the term in the original language. The words such as nge-spam, spot, upload, di-reject, and miscall are words that are related to technical communication and social media. Obviously, technical terminology is firmly connected with English. The singers maintained these English words because they are common terms, particularly among social media users. This is in line with Hoffmann (2014) 
and Myers-Scotton (1993) who postulate that a lack of facility in the relevant register results in CS. Other phrases such as rock and roll, check it out, and poser, were also preferred to be in English because translating such words to BI might cause them to be less semantically correct, and sometimes they cannot be used. It was found that to fulfill lexical needs and availability, the intrasentential CS and CS involving a change of pronunciations are commonly used in the song.

\section{Being Emphatic About Something}

Code-switching also functions as a way to show emphatic and sympathy toward someone or something. In this study, it was found that the switch happens because using English words to express these feelings may have a higher impact on the listeners. Moreover, showing compassion and empathy in a foreign language might be more comfortable than in the native language. An excerpt (22), (23), (27) for example, the singers clearly display their sympathy and attempt to motivate the listeners to move forward. Hoffmann (2014) sees people code-switching, intentionally or unintentionally, to their first language when they want to be emphatic about something or it is more convenient to be emphatic using a foreign language instead of the first language. In an excerpt (27) for example, "Hatiku rasakan cinta, dia buatku salah tingkah I know you so well", the singer indicated that he is the one that understands him/her better. Within this function, intersentential CS was particularly found.

\section{Convey Strong Emotion or to Gain Attention}

Interjection or sentence filler is defined as words, phrases, or expressions that are used to convey strong emotions or to gain attention. This function of CS can be found in excerpts (31), (32), (33), and (35). In excerpt (31), for instance, it is feasible that the singer intends to convey strong feelings because the lyrics are about nationalism, where the country national motto satu jiwa (one soul), satu darah (one blood), satu rasa (one taste) are commonly used to raise the spirit of national unity.

Moreover, it may also happen that the singers just simply borrow words or phrases that are frequently used in some types of songs and contexts. In excerpt (32), there is the exclamation phrase, oh my God, to express excitement for having such good parents. Since this phrase is frequently used in conversation when people intend to show excitement or to gain attention, there is a possibility that the singer's intention to borrow this token to be used in the lyrics. In excerpt (33), the songwriter inserted the English phrase, hey you know, then continued the rest of the lyrics in BI to get the audience's attention. Finally, in excerpt (35), there is the English exclamation, yeah, at the beginning of the sentence, which might be used to display confirmation. In 
this line, it means agreement with the lyrics where it means (yeah) ini adalah cara yang sama untuk me-respek perbedaan (this is a way to respect the difference). Hoffmann (2014) mentions that interjections might happen intentionally or unintentionally and can be found in language switching in bilingual or multilingual groups. To convey emotions, the emblematic type of CS was mainly found in Indonesian popular songs evaluated in this study.

\section{Expressing Bilingual Identity and Group Characteristics}

Code-Switching is also used to represent identities, such as bilingual ability and belonging to a to a specific group. For instance, the ways teenage groups communicate are different from adult discussion groups. CS in song lyrics that fulfills this function can be found in the following examples. Excerpt (19) we're zig zag family sebelas anak plus orang tua (eleven kids plus the parents) shows the singer's intention to identify himself as part of a big family. Additionally, in excerpt (20) Keluarga Halilintar (the Halilintar family), you can call us whatever, there is a code-switch from BI to English when the songwriter emphasizes his family identity. Accordingly, the singer might also want to display their ability in speaking different languages. In an excerpt (21), there is a CS from BI to English jangan pernah berputus asa jadi yang terbaik (do not give up to be the best) show the world you are as bright as the sun. This song is the official song for the Asian games 2018, which were held in Jakarta, Indonesia. To understand the purpose of CS in this song, we might need to analyse the lyrics thoroughly. However, based on the lyrics, in excerpt (21), the singers aim to give support and to show their national identity as Indonesian as well as an athlete. Finally, excerpt (40) Fivers tetaplah kau di sini, kibarkan bendera kita (stay here, wave our flag) clearly shows the intention to express a group identity where the word fivers refers to a group of community. In expressing group identity, both intrasentential and intersentential code-switching are found within the Indonesian song lyrics.

\section{The Potential Implications for English Language Teaching}

The use of CS in Indonesian popular songs has several implications for the teaching of English in Indonesia. These findings are beneficial for English teachers to construct their teaching materials using popular songs when targeting specific aspects of the language such as pronunciation, vocabulary, and grammar. For students, using music and songs when learning a foreign language undoubtedly contributes to a positive learning environment (Ulate, 2008), provides comprehensible input (Krashen, 1987), and increases motivation (Harmer, 2001). Language classes can often turn out to be monotonous, stressful, and tiring, therefore, listening to music might offer a different learning procedure in the classroom (Lo \& Li, 1998; Ulate, 2008). Listening to popular songs that contain students' first and target language 
will help them to become more familiar with English words and sentences as well as teaching them a variety of language structures, vocabulary, pronunciation, parts of speech, etc. However, regarding pronunciation, it should be remembered that considering the singer may not be a native English speaker, if the singer pronounces the words in the wrong way, it will significantly affect the students' pronunciation, too. Similarly, if the grammatical rules of the lyrics are not in Standard English, students will learn something incorrectly. Repetition of English words, phrases, and expressions that appear significantly often in Indonesian popular songs might help students to memorize such words. Considering Krashen's (1987) Input Hypothesis, songs become an excellent opportunity for students to acquire the new language while at the same time motivating them by making them learn in an enjoyable environment.

For the English language teacher, employing CS practices between the first language and the second language in the process of teaching and learning might become a pedagogical tool and a crucial educational resource. CS between first and second language has been seen as advantageous in increasing students' exposure to the target language (Littlewood \& Yu, 2011; Sakaria \& Priyana, 2018) and in improving their performance (Borlongan et al., 2012) because students learn better in a language, they are more comfortable with it. Moreover, using Indonesian popular songs that have CS in them can be considered a teaching aid. It functions as a compelling approach to execute orders as well as a means to emphasize critical key terms. Last but not least, using CS songs means that the teacher is aware of CS as a phenomenon and should tolerate students who code-switch in the classroom. The use of CS is no longer seen as a language deficiency but strategic use of the various linguistic repertoires (Borlongan, 2012). As a learning strategy in a multilingual classroom, students are not only learning in the target language but are also developing and maintaining their mother tongue (additive bilingualism). Cenoz (2007) argues that bilinguals have a more developed metalinguistic awareness than monolinguals. Cenoz recommends for teachers to utilize L1 knowledge to perform "contrastive analysis" between L1 and English (2007, p.136). In support of multilingual classroom practice, Cook (2002) states "noting that language learners are aiming to become competent L2 users, and not native speakers and that competent L2 users code-switch in their daily practices" (p. 332). With respect to the different functions of CS, as found in this study, teachers may build the students' awareness of CS in a way that CS may serve for various purposes and functions. For instance, the intention to discuss particular topics and to reach a large population may need to be conducted in different languages. Moreover, to fulfill lexical needs, some words may not always be available in the students' L1 language; therefore, there is a need to use another language in their repertoire. Consequently, they 
become aware that CS is not a language insufficiency but a linguistic norm in a bi/multilingual society.

\section{CONCLUSION AND SUGGESTION}

Because the subject of CS is an extensive topic to discuss, I limited my research to find the types of CS that appear in Indonesian popular songs and looking at the reasons why the songwriters use CS in their lyrics. This study reveals that CS between BI and English in Indonesian popular songs involves four types of CS; intersentential, intrasentential, CS involves a change of pronunciation and emblematic code-switching. Moreover, based on the analysis, it was found that there were several reasons for the songwriters to switch from BI to English. First, when talking about particular topics, the singers attempt to avoid mentioning some issues in BI on which the public has strong opposite opinions. Second is the lack of finding equal translation in BI. It is also found that when there is an intention to show empathy to someone or something, the lyrics switch to English. The fourth reason is intentions to show strong or sudden emotions about something. Since English has fewer syllables than BI, the singer shortens the words or expressions to fit the rhythm. Finally, CS serves as a tool for expressing group identity. With the development of CS studies conversational speech, this study will significantly contribute to the study of CS in different contexts such as music and lyrics. The application of CS in song lyrics in ESL or EFL classrooms will be beneficial for future studies.

\section{ACKNOWLEDGEMENT}

I would like to express my gratitude to Prof. Hanh Thi Nguyen, Hawaii Pacific University, for sharing her pearls of wisdom with me during the course, and I thank Jenny Osorio, University of Alberta, for her comments on an initial version of the document. Any errors are mine, and they should not tarnish the reputations of these respected people.

\section{REFERENCES}

Auer, P. (1998). Code-Switching in conversation: Language, interaction, and identity. Routledge.

Babalola, E. T., \& Taiwo, R. (2009). Code-switching in Contemporary Nigerian hip-hop music. Online Journal of African Studies, (1), 1-26.

Bentahila, A., \& Davies, E. E. (2002). Language mixing in rai music: Localisation or globalisation? Language $\mathcal{E}$ Communication, 22(2), 187207. https:/ / doi.org/10.1016/S0271-5309(01)00026-X

Blom, J., \& Gumperz, J. J. (1972). Social meaning in linguistic structures: Code switching in northern Norway. In J. Gumperz and D. Hymes (Eds.), Directions in sociolinguistics: The ethnography of communication, (pp. 407- 
434). Holt, Rinehart and Winston.

Borlongan, A. M. (2012). Reflecting on the use of code-switching in Philippine education today. TESOL Journal, 7, 78-80.

Borlongan, A. M., Lim, J., \& Roxas, R. E. O. (2012). University students' attitudes towards English-Tagalog code-switching in classroom instruction. TESOL Journal, 7, 70-77.

British Council. (2021). Indonesia Foundation. https://www.britishcouncilfoundation.id/en/english/articles/langu age-main-differences\#main-content

Cenoz. (2007). The acquisition of pragmatic competence and multilingualism in foreign language contexts. In E. Alcon Soler and M. P. Safont Jorda (eds.), Intercultural language use and language learning (pp. 123-140). Springer.

Cook, V. (2002). Language teaching methodology and the L2 user perspective. In V. J. Cook (eds.). Portraits of the L2 user (pp. 325-344). Multilingual Matters. https://doi.org/10.21832/9781853595851-015

Creswell, J. W. (2007). Qualitative inquiry \& research design: Choosing among five approaches (2nd ed.). Sage Publication.

Davies, E. E., \& Bentahila, A. (2006). Code switching and the globalisation of popular music: The case of North African rai and rap. Multilingual Journal of Cross-Cultural and Interlanguage Communication, 25(4), 367392.

Davies, E. E., \& Bentahila, A. (2008). Translation and code switching in the lyrics of bilingual popular songs. The Translator, 14(2), 247-272. https://doi.org/10.1080/13556509.2008.10799258

Gumperz, J. J. (1982). Discourse strategies. Cambridge University Press. https://doi.org/10.1017/CBO9780511611834

Harmer, J. (2001). The practice of English language teaching (3rd Ed.). Longman.

Hoffmann, C. (2014). Introduction to bilingualism. Routledge. https://doi.org/10.4324/9781315842035

Korneliussen. I. (2012, May 25). Stay in control or display emotions? Different cultures express emotions in various manners. Indonesians and Norwegians, for example, grieve in very different ways. Science Norway. https:/ / sciencenorway.no/culture-emotions-forskningno/stay-incontrol-or-display-emotions/1372254.

Krashen, S. D. (1987). Principles and practice in second language acquisition. Prentice-Hall International.

Littlewood, W., \& Yu, B. (2011). First language and target language in the foreign language classroom. Language Teaching, 44(1), 64-77.

Lo, R. S. M., \& Li, H. C. F. (1998). Songs enhance learner involvement: Materials development. Forum, 36(3). 
Mattsson, A. F., \& Burenhult, N. (1999). Code-switching in second language teaching of French. Department of Linguistics Working Papers, 47, 59-72. Lund University.

McArthur, T. M. (2003). Code-mixing and code-switching. In T. McArthur (Eds.), Concise Oxford companion to the English language (1st Ed). Oxford University Press.

Milroy, L., \& Gordon, M. J. (2003). Sociolinguistics: Method and interpretation. Blackwell Pub.

Moeljadi, D., Da Costa, M. L., \& Bond, F. (2016). Basic copula clauses in Indonesian. Conference Proceedings on Head-Driven Phrase Structure Grammar and Lexical Functional Grammar, 442-456.

Muysken, P. (2000). Bilingual speech: A typology of code-mixing. Cambridge University Press.

Myers-Scotton, C. (1993). Social motivations for codeswitching: Evidence from Africa. Clarendon Press.

Myers-Scotton, C. (2006). Multiple voices: An introduction to bilingualism. Blackwell.

Poplack, S. (1980). Sometimes I'll start a sentence in Spanish y termino en español: Toward a typology of code-switching. Linguistics, 18(7), 581618. https:/ / doi.org/10.1515/ling.1980.18.7-8.581

Sarkar, M., Winer, L., \& Sarkar, K. 2005. Multilingual code-switching in Montreal hip-hop: Mayhem meets method, or, 'Tout moune qui talk trash kiss mon black ass du nord'. The Proceedings of the 4th International Symposium on Bilingualism. Cascadilla Press. ISBN 2057-2074.

Sakaria, S., \& Priyana, J. (2018). Code-switching: A pedagogical strategy in bilingual classrooms. American Journal of Educational Research, 6(3), 175180. https://doi.org/10.12691/education-6-3-3

Ulate, N. V. (2008). Using songs to improve EFL students' pronunciation. LETRAS, 44, 93-108.

Wardhaugh, R., \& Fuller, J.M. (2015). An Introduction to sociolinguistics. WileyBlackwell.

Wieringa, E. (2010). Writing love: expressing nearness and dearness in Malay-language love letters. Indonesia and the Malay World, 31(91), 317-338. Https:// doi.org/10.1080/1363981042000188628. 